\title{
Silvicultural Potential of Handroanthus heptaphyllus Under Doses of Controlled Release Fertilizer and Container Volume, in Nursery and in the Field
}

\author{
Jessé C. Mezzomo ${ }^{1}$, Maristela M. Araujo ${ }^{1}$, Felipe Turchetto ${ }^{2}$, Daniele G. Rorato ${ }^{1}$, Adriana M. Griebeler ${ }^{1}$, \\ Álvaro L. P. Berghetti ${ }^{1} \&$ Felipe M. Barbosa ${ }^{1}$ \\ ${ }^{1}$ Department of Forest Sciences, Federal University of Santa Maria, Santa Maria, Rio Grande do Sul, Brazil \\ ${ }^{2}$ Academic Coordination, Federal University of Santa Maria, Cachoeira do Sul, Rio Grande do Sul, Brazil \\ Correspondence: Felipe Turchetto, Federal University of Santa Maria, Academic Coordination, 1345, Cachoeira \\ do Sul, RS, 96506-322, Brazil. E-mail: turchetto.felipe@gmail.com
}

Received: June 30, $2018 \quad$ Accepted: August 5, $2018 \quad$ Online Published: October 15, 2018

doi:10.5539/jas.v10n11p389 URL: https://doi.org/10.5539/jas.v10n11p389

\begin{abstract}
The present study aimed to characterize the growth of Handroanthus heptaphyllus seedlings in a nursery, planted under different container volumes and doses of controlled release fertilizer (CRF), and to verify whether the responses obtained in the nursery are confirmed in the field. For the production of seedlings in the nursery, three volumes of container (180 and $280 \mathrm{~cm}^{3}$ polypropylene tubes and $500 \mathrm{~cm}^{3}$ polyethylene bags) and four CRF doses $\left(0,4,8\right.$, and $12 \mathrm{~g} \mathrm{~L}^{-1}$ of substrate) were used. At $180 \mathrm{~d}$ after emergence, height (H), stem diameter (SD), H:SD ratio, shoot dry weight, root dry weight, total dry weight, Dickson Quality Index, leaf area, root length, and fluorescence of chlorophyll $a$ were evaluated. The same treatments were evaluated again in the field $540 \mathrm{~d}$ after planting, and the survival, increase in $\mathrm{H}$ and SD, as well as shoot dry weight, leaf area, chlorophyll fluorescence, and chlorophyll index ( $a, b$ and total) were measured. In the nursery, seedlings of $H$. heptaphyllus responded positively to the volume of the container, as well as the base fertilization using CRF. However, when planted in the field, the plants that received the best nutritional conditions in the nursery showed good performance and was favored in the field. Thus, in the production of quality seedlings, the use of containers of the type polypropylene tubes with $180 \mathrm{~cm}^{3}$, and basic fertilization with $12 \mathrm{~g} \mathrm{~L}^{-1}$ of CRF conditions that enable growth of $H$. heptaphyllus in the field are recommended.
\end{abstract}

Keywords: forest seedlings, containers, mineral nutrition, field

\section{Introduction}

Handroanthus heptaphyllus (Mart.) Mattos (ipê-roxo) is a species belonging to the family Bignoniaceae, occurring in South America, Africa, and Asia (Tropicos, 2017). The species is classified as deciduous, heliophilous, and is commonly found in secondary vegetation (Lorenzi, 2002; Carvalho, 2003).

The species has potential for timber, medicinal, landscape and ecological uses. Handroanthus heptaphyllus wood is of high quality, with a naturally high durability and resistance to insect attack and decay (Backes \& Irgang, 2002; Campos Filho \& Sartorelli, 2015). The bark contains phenolic compounds that help in the treatment of diabetes (Grochanke et al., 2016). It is widely used in urban afforestation and is also suitable for the restoration of riparian forests in places with no periodic flooding (Carvalho, 2003; Coradin et al., 2011).

The great potential of this species, combined with the increased demand for native forest species, makes it essential to define strategies and protocols for the production of quality seedlings (Dutra et al., 2016), which are essential for the initial success of forest plantations (Gasparin et al., 2014). Among the factors that most influence the quality of the seedlings this experiment focusses on container volume and base fertilization.

The volume of the container should allow for the development of the root system without imposing restrictions during the period of permanence of the seedling in the nursery (Carvalho Filho et al., 2003). The use of containers with volumes smaller than what is recommended causes deformations of the radicular system, like the folding of the roots (Freitas et al., 2005), while containers with volumes larger than what is recommended lead to unnecessary expenses regarding substrate (Viana et al., 2008) and fertilizers. Thus, to determine the ideal volume 
of the container, it is necessary to consider the speed of growth and morphology of the root system of the species to be produced, as well as the financial resources.

Basic fertilization is essential to maximize seedling growth (Klooster et al., 2012). However, both excess and lack of nutrients can be harmful to plants (Gonçalves et al., 2005). The quantity and characteristics of the fertilizers to be used in the production of forest seedlings depend on the form of reaction and efficiency in the release of these, as well as on the nutritional requirement of the species (Gonçalves et al., 2004). In this sense, we highlight the use of controlled release fertilizers (CRF), which increase the efficiency of fertilization because, according to Elli et al. (2013), they provide nutrients on a regular and continuous basis to the seedlings, and reducing leach losses (Shaviv, 2001).

The objective of this study is to characterize the growth of $H$. heptaphyllus seedlings in the nursery-produced in different container volumes and doses of controlled release fertilizer-and verify whether the responses obtained in the nursery are confirmed in the field.

\section{Material and Methods}

\subsection{Seedlings Grown in Nursery}

The experiment was conducted at the Forest Nursery $\left(29^{\circ} 43^{\prime} \mathrm{S}\right.$ and $\left.53^{\circ} 43^{\prime} \mathrm{W}\right)$ at the Federal University of Santa Maria (UFSM), Rio Grande do Sul (RS), Brazil, from March 2014 to September 2014. According to the classification of Köppen, the climate of the region is subtropical, type $\mathrm{Cfa}$, with an average annual precipitation of $1720 \mathrm{~mm}$ and average annual temperature of $19.1^{\circ} \mathrm{C}$, with $32{ }^{\circ} \mathrm{C}$ and $9{ }^{\circ} \mathrm{C}$ as the averages of the hottest and coldest months, respectively (Heldwein et al., 2009).

The experimental design was completely randomized with three replicates in a factorial scheme $(3 \times 4)$, considering three container volumes [polypropylene containers (cylindrical and conical) of 180 and $280 \mathrm{~cm}^{3}$, and polyethylene bags (with lateral perforations) of $\left.500 \mathrm{~cm}^{3}\right]$ and doses of CRF $\left(0,4,8\right.$, and $12 \mathrm{~g} \mathrm{~L}^{-1}$ of substrate). Each experimental unit was composed of 20 seedlings.

A 2:1 mixture of commercial substrate (composed of Sphagnum peat and expanded vermiculite) and carbonized rice husk were used to fill the containers. The CRF used in the base fertilization had a release time of 5-6 mo. and the following chemical composition: macronutrients $15 \%$ nitrogen $(\mathrm{N}) ; 9 \%$ superphosphate $\left(\mathrm{P}_{2} \mathrm{O}_{5}\right) ; 12 \%$ potassium chloride $\left(\mathrm{K}_{2} \mathrm{O}\right) ; 1 \%$ magnesium $(\mathrm{Mg})$ (Mgeni and Price, 1993), and the micronutrients $2.3 \%$ sulfur $(\mathrm{S})$; $0.05 \%$ copper $(\mathrm{Cu}) ; 0.06 \%$ manganese (Mn) (Zór et al., 2017); $0.45 \%$ iron ( $\mathrm{Fe}$ ), and $0.2 \%$ molybdenum (Mo).

The seeds used in the study were collected in the city of Ijuí, RS, Brazil. At sowing, two seeds were used per container, and after $60 \mathrm{~d}$ it was thinned to leave only the most vigorous and central seedling. The seedlings remained in a greenhouse, where they received irrigation from a micro sprinkler $\left(5 \mathrm{~mm} \mathrm{day}^{-1}\right)$.

At the end of the experiment (120 d after thinning) the seedlings were evaluated, and the following attributes were recorded: height $(\mathrm{H})$, stem diameter $(\mathrm{SD}), \mathrm{H}: \mathrm{SD}$ ratio, leaf area (LA), root length (RL), shoot dry weight (SDW) (Omari et al., 2016), root dry weight (RDW), and chlorophyll $a$ fluorescence.

$\mathrm{H}(\mathrm{cm})$ was measured from the substrate level to the apical bud using a graduated ruler. SD was evaluated at the substrate level, using a digital caliper (accuracy of $0.01 \mathrm{~mm}$ ). From these data, the H:SD was obtained. In the quantification of LA and RL, two plants were measured per treatment. The aerial parts and the roots were separated from each other, the roots were washed in water using sieves, and then both were distributed on A4 white paper containing a scale. Photographs were obtained with a SONY digital camera (model DSC-T100) and processed using the Image $₫($ program.

SDW and RDW were determined using the same samples used to evaluate LA and RL. The aerial parts and the roots were dried in an air circulation oven at $65{ }^{\circ} \mathrm{C}$ until constant weight. They were then weighed using a precision digital scale $(0.001 \mathrm{~g})$. The total dry mass (TDW) was obtained from the sum of SDW and RDW. From these data, the Dickson quality index (DQI) was calculated according to Dickson et al., (1960).

The fluorescence of chlorophyll $a$ analysis was performed using JUNIOR-PAM modulated pulse fluorometer (Walz, Germany) from 07:00 to 23:00, and a molt from each replicate was randomly selected. For evaluations, a fully expanded leaf of the second branch was pre-adapted to the dark for $30 \mathrm{~min}$. The reading was then taken, obtaining values for the initial fluorescence (F0), maximum fluorescence (Fm), maximum quantum yield $(\mathrm{Fv} / \mathrm{Fm})$, and electron transport rate (ETR). 


\subsection{Planting Seedlings in the Field}

The experiment was conducted from October 2014 to April 2016, in an area adjacent to the Forest Nursery of the UFSM (29 $43^{\prime} 12^{\prime \prime} \mathrm{S}$ and $\left.53^{\circ} 43^{\prime} 14^{\prime \prime} \mathrm{W}\right)$, in a randomized block design, formed by the 12 treatments previously tested. Each plot was composed of four plants, totaling 144 plants.

For planting, circular pits $30 \mathrm{~cm}$ in diameter and $35 \mathrm{~cm}$ deep were opened with a soil boring machine coupled to a tractor, spaced $1 \mathrm{~m}^{2}$ apart. The soil chemical characteristics of the area were analyzed by the Soil Analysis Laboratory (UFSM) (Table 1) and guided pH correction with dolomitic limestone (PRNT 74\%) $30 \mathrm{~d}$ prior to planting.

Table 1. Chemical attributes of the soil where H. heptaphyllus seedlings were planted

\begin{tabular}{|c|c|c|c|c|c|c|c|c|}
\hline $\mathrm{pH}$ & $\mathrm{P}^{*}$ & $\mathrm{~K}$ & $\mathrm{Ca}$ & $\mathrm{Mg}$ & $\mathrm{Al}$ & MO & Clay & V \\
\hline $\mathrm{H}_{2} \mathrm{O}$ & \multicolumn{2}{|c|}{------- $\mathrm{mg} \mathrm{dm}{ }^{-3}$------- } & \multicolumn{3}{|c|}{---------------- cmolc dm³ } & \multicolumn{3}{|c|}{---------------------- \% --------------------- } \\
\hline 4.4 & 4.5 & 36.0 & 2.0 & 0.6 & 1.8 & 2.1 & 31.0 & 13.3 \\
\hline
\end{tabular}

Note. In which: P: phosphorus * extracted by the method of Mehlich I; K: potassium; Ca: calcium; Mg: magnesium; $\mathrm{Al}$ : aluminum; $\mathrm{MO}$ : organic matter; $\mathrm{V}$ : base saturation.

Seedlings were irrigated once per week during the first month, adding $2 \mathrm{~L}$ of water per seedling. Fertilization was provided at 30,210, and $390 \mathrm{~d}$ after planting by applying $100 \mathrm{~g}$ of NPK (05-20-20) in the first two fertilizations and $50 \mathrm{~g}$ of $\mathrm{N}$ in the last fertilization.

$\mathrm{H}$ and SD were measured at planting and at the end of the experiment ( 0 and $540 \mathrm{~d}$ after planting), through which the increase in height (IH) and stem diameter (ISD) were obtained.

At $540 \mathrm{~d}$ after planting, the survival and determination of LA and SDW were evaluated. We additionally evaluated the physiological attributes: chlorophyll index ( $a, b$, and total) in two plants per replicate, using a chlorophyll LOG (Falker Automação Agrícola, Brazil) chlorophyllometer and fluorescence of chlorophyll $a$ in a seedling per replicate.

\subsection{Statistical Analysis}

In both experiments, we evaluated the assumptions of normality of the residuals and homogeneity of variance. The data were analyzed by a two-way analysis of variance (ANOVA) and subsequent comparison of the means by a Tukey test or regression analysis at $5 \%$ probability of error. The analyses were conducted in the statistical package SISVAR (Ferreira, 2014).

\section{Results}

\subsection{Seedlings Grown in Nursery}

For $\mathrm{H}$ and TDW, we observed a significant effect for the CRF dose (Figure 1) and container volume. The dose of maximum technical efficiency (MTE) estimated for $\mathrm{H}(8.16 \mathrm{~cm})$ was $10 \mathrm{~g} \mathrm{~L}^{-1}$ of CRF. TDW presented linear growth with increasing CRF doses, with the highest average observed in doses of $12 \mathrm{~g} \mathrm{~L}^{-1}(0.89 \mathrm{~g})$, representing an increase of $111.9 \%$ relative to the control $\left(0 \mathrm{~g} \mathrm{~L}^{-1}\right)$. 

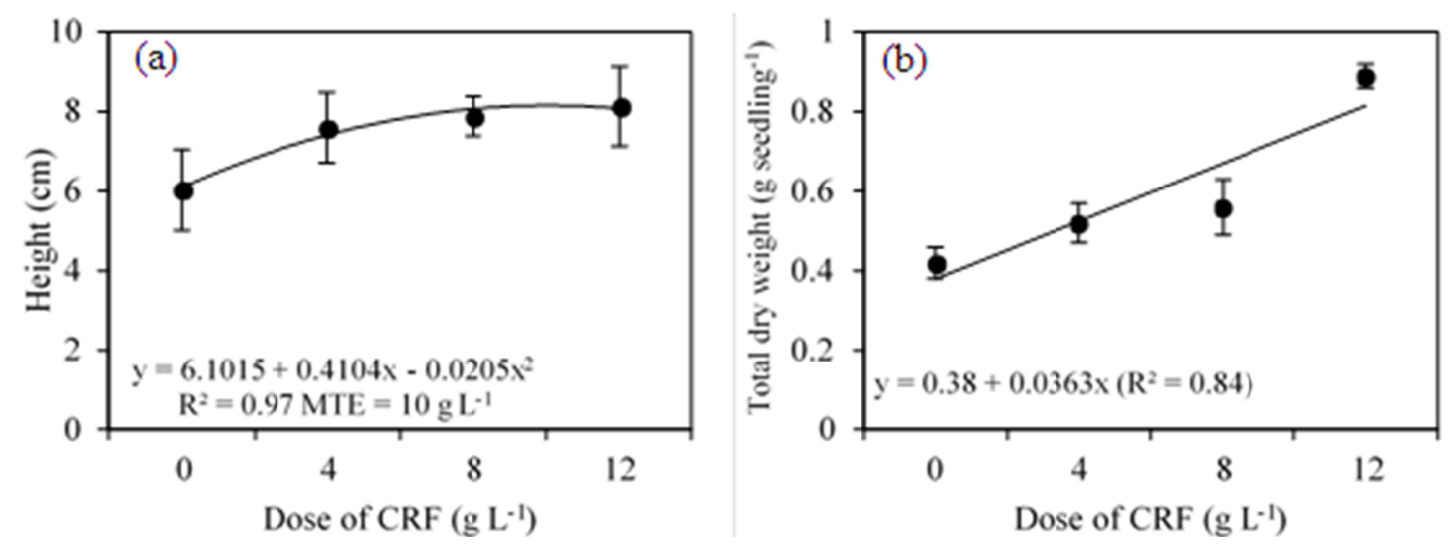

Figure 1. Height (a) and total dry weight (b) of Handroanthus heptaphyllus seedlings, at $120 \mathrm{~d}$ after thinning, as a function of controlled release fertilizer (CRF) dose, in nursery

Concerning the effect of container volume, seedlings produced in polyethylene bags of $500 \mathrm{~cm}^{3}$ presented the highest averages for $\mathrm{H}(8.17 \mathrm{~cm})$ and TDW $(0.78 \mathrm{~g})$ (Table 2).

Table 2. Height and total dry weight of Handroanthus heptaphyllus seedlings, at $120 \mathrm{~d}$ after thinning, as a function of container volume, in nursery

\begin{tabular}{|c|c|c|}
\hline & Height $(\mathrm{cm})$ & Total dry weight $\left(\mathrm{g}\right.$ plant $^{-1}$ ) \\
\hline Tubes $180 \mathrm{~cm}^{3}$ & $6.91 \quad b^{*}$ & $0.48 \quad b^{*}$ \\
\hline Tubes $280 \mathrm{~cm}^{3}$ & 7.16 & 0.54 \\
\hline Polyethylene bags $500 \mathrm{~cm}^{3}$ & 8.17 & 0.78 \\
\hline
\end{tabular}

Note. * Means followed by the same letter in the column do not differ by Tukey test at $5 \%$ of error probability.

CRF doses demonstrated significant effects on the RDW, DQI, and H:SD attributes (Figure 2). The highest RDW $(0.38 \mathrm{~g})$ and DQI $(0.38)$ were achieved at a dose of $12 \mathrm{~g} \mathrm{~L}^{-1}$, while H:SD showed an MTE of $8.4 \mathrm{~g} \mathrm{~L}^{-1}$ of CRF (3.73) (Figure 2). 

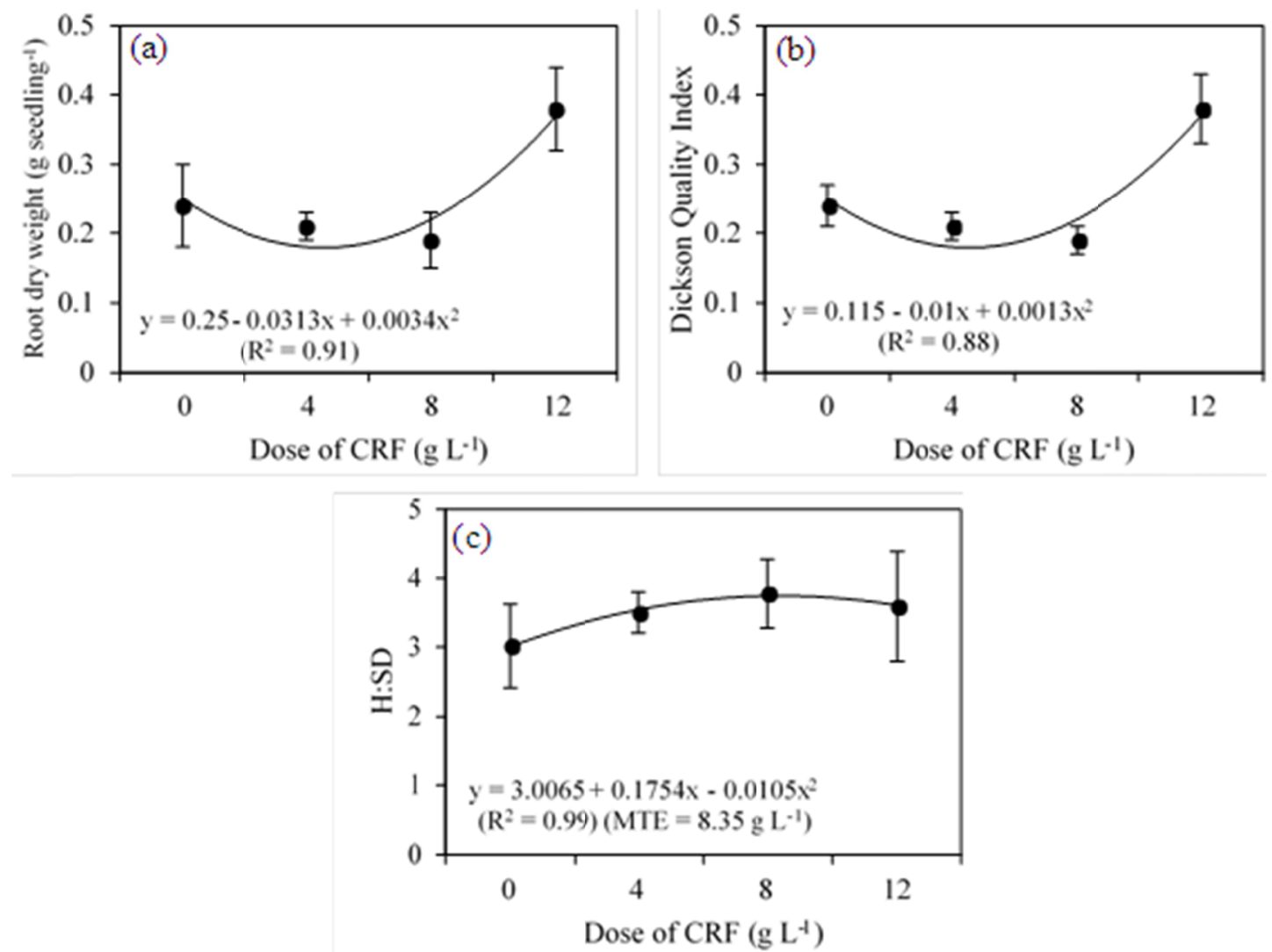

Figure 2. Root dry weight (a), Dickson quality index (b), and H:SD ratio (c) of Handroanthus heptaphyllus seedlings at $120 \mathrm{~d}$ after thinning, as a function of controlled release fertilizer (CRF) dose, in nursery

SDW, LA, and RL demonstrated significant interactions between the study factors. The SDW presented quadratic behavior for the $180 \mathrm{~cm}^{3}$ tube and the $500 \mathrm{~cm}^{3}$ bag, and linear behavior for the $280 \mathrm{~cm}^{3}$ tube relative to the CRF dosage (Figure 3). The MTE estimated for the $180 \mathrm{~cm}^{3}$ tube was $7.2 \mathrm{~g} \mathrm{~L}^{-1}(0.39 \mathrm{~g})$. The highest values for the $280 \mathrm{~cm}^{3}$ tube $(0.39 \mathrm{~g})$ and $500 \mathrm{~cm}^{3}$ bag $(0.87 \mathrm{~g})$ were obtained at the maximum CRF dose $\left(12 \mathrm{~g} \mathrm{~L}^{-1}\right)$.

LA exhibited a quadratic tendency as a function of the containers and doses of CRF (Figure 3b). In this case, the MTE found for the $180 \mathrm{~cm}^{3}$ and $280 \mathrm{~cm}^{3}$ tubes were $7.9 \mathrm{~g} \mathrm{~L}^{-1}$ and $10.3 \mathrm{~g} \mathrm{~L}^{-1}$, respectively; a dose of $12 \mathrm{~g} \mathrm{~L}^{-1}$ in the $500 \mathrm{~cm}^{3}$ bag provided the highest mean $\left(113.94 \mathrm{~cm}^{2}\right)$. 

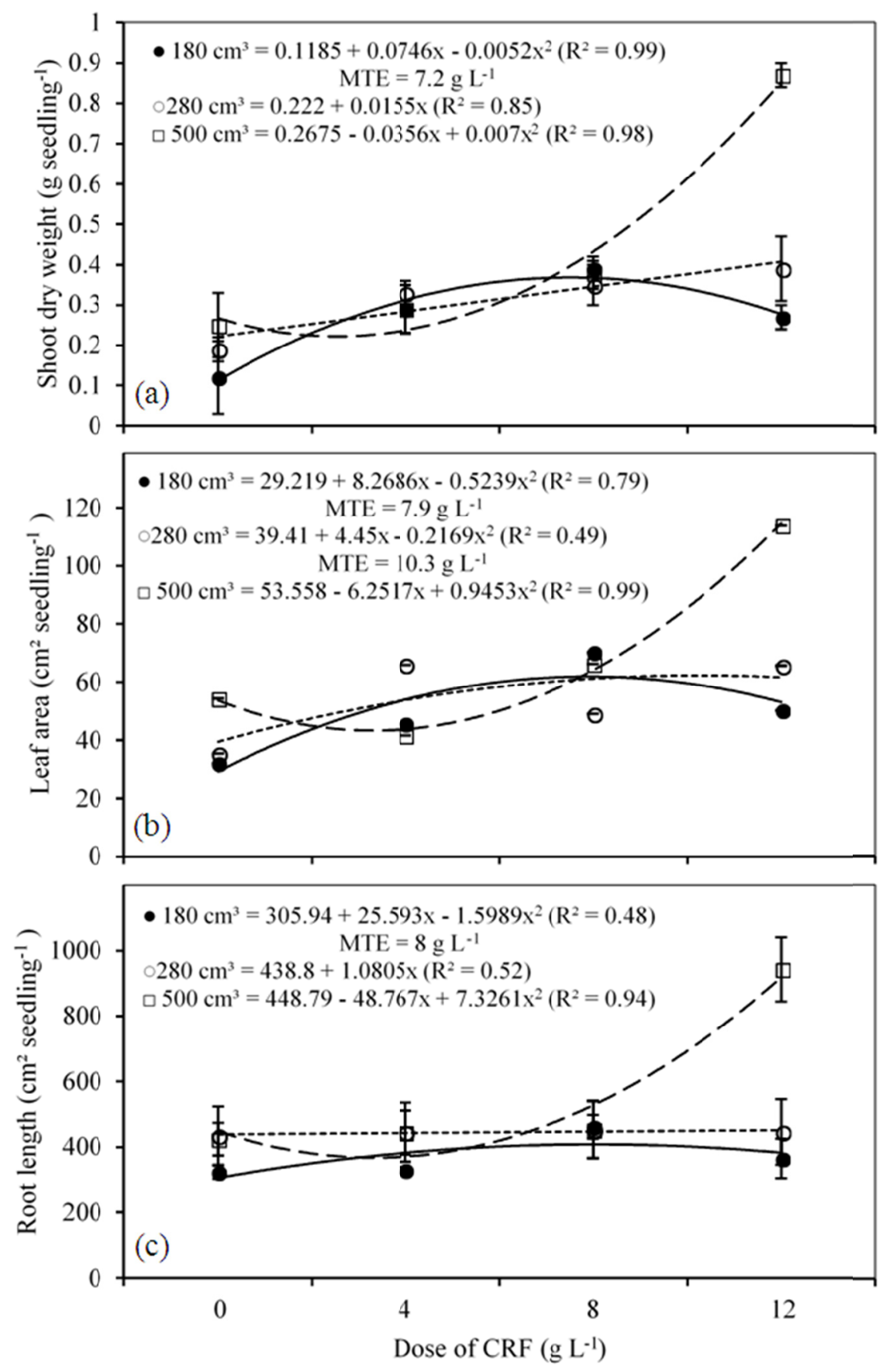

Figure 3. Shoot dry weight (a), leaf area (b), and root length (c) of Handroanthus heptaphyllus seedlings at $120 \mathrm{~d}$ after thinning, as a function of controlled release fertilizer (CRF) dose, in nursery

The RL presented a trend similar to that observed for DDW. In the tubes of $180 \mathrm{~cm}^{3}$ and $280 \mathrm{~cm}^{3}$ MTE was observed at $8 \mathrm{~g} \mathrm{~L}^{-1}$; while for the bag of $500 \mathrm{~cm}^{3}$, the dose of $12 \mathrm{~g} \mathrm{~L}^{-1}$ provided the highest RL $(943.09 \mathrm{~cm})$, representing an increase of $122.3 \%$ relative to the control.

The maximum quantum yield differed in relation to the CRF doses, exhibiting a positive linear trend. The highest mean (0.57) was observed at a CRF dose of $12 \mathrm{~g} \mathrm{~L}^{-1}$ (Figure 4). 


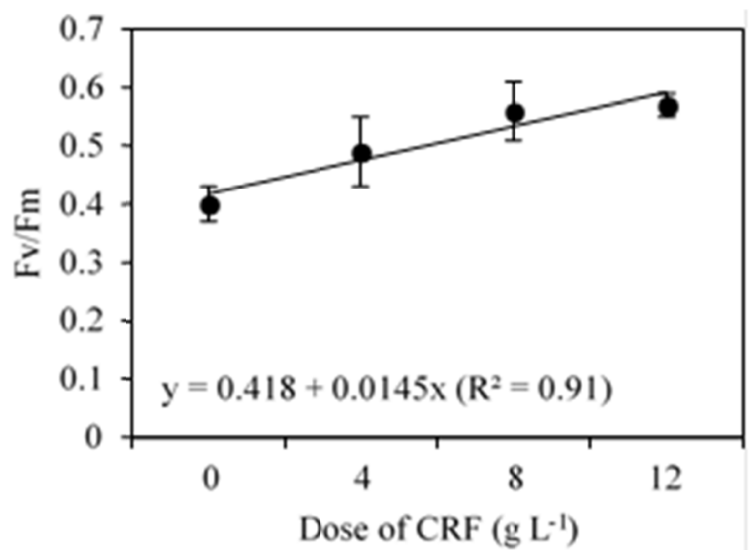

Figure 4. Maximum quantum yield $\left(\mathrm{F}_{\mathrm{v}} / \mathrm{F}_{\mathrm{m}}\right)$ of Handroanthus heptaphyllus seedlings, evaluated at $120 \mathrm{~d}$ after thinning, as a function of controlled release fertilizer (CRF) dose, in nursery

\subsection{Planting Seedlings in the Field}

The survival of the seedlings in the field was approximately $60 \%$ at $540 \mathrm{~d}$ after planting. CRF dosage significantly affected IH, ISD, SDW, LA, Fv/Fm, and the chlorophyll $a$ index; however interaction between CRF doses and container volumes was not witnessed.

IH and SDW showed a quadratic behavior with increasing CRF doses, while ISD and LA presented linear trends. However, in all variables, the highest averages $\left(99.53 \mathrm{~cm}, 22.08 \mathrm{~mm}, 169.83 \mathrm{~g}\right.$ and $6618.35 \mathrm{~cm}^{2}$, respectively) were observed for a CRF dosage of $12 \mathrm{~g} \mathrm{~L}^{-1}$ (Figure 5).
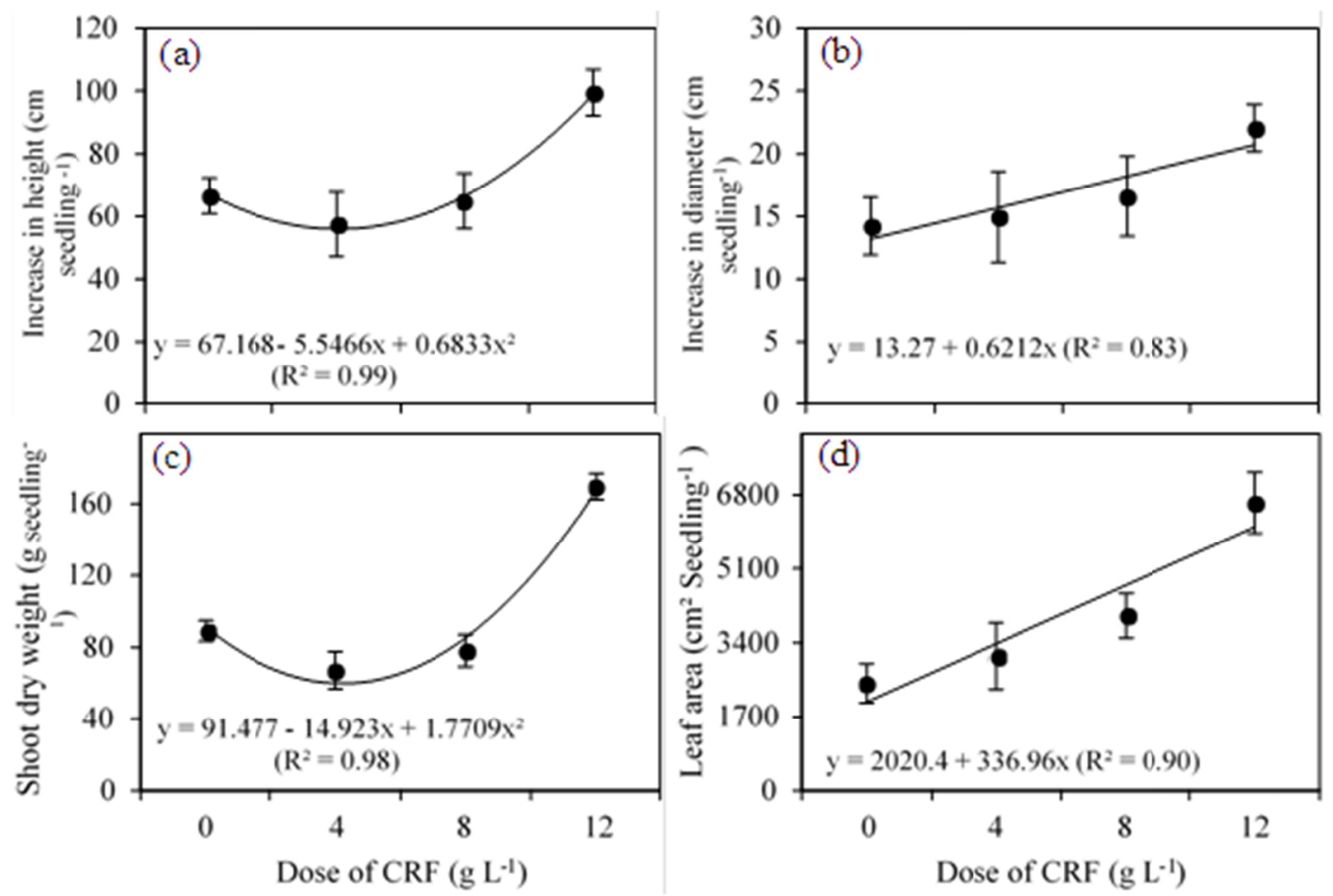

Figure 5. Increase in height (a), increase in stem diameter (b), shoot dry weight (c), and leaf area (d) of Handroanthus heptaphyllus seedlings at $540 \mathrm{~d}$ after planting, depending on the controlled release fertilizer (CRF) dose, in field 
The $\mathrm{F}_{\mathrm{v}} / \mathrm{F}_{\mathrm{m}}$ presented a positive linear trend with CRF doses, with the highest mean $(0.54)$ verified in the dose of $12 \mathrm{~g} \mathrm{~L}^{-1}$ of CRF (Figure 6). For the chlorophyll $a$ index, there was a quadratic trend as a function of CRF dose (Figure 6), with an estimated MTE for the $8.7 \mathrm{~g} \mathrm{~L}^{-1}$ dose of CRF.
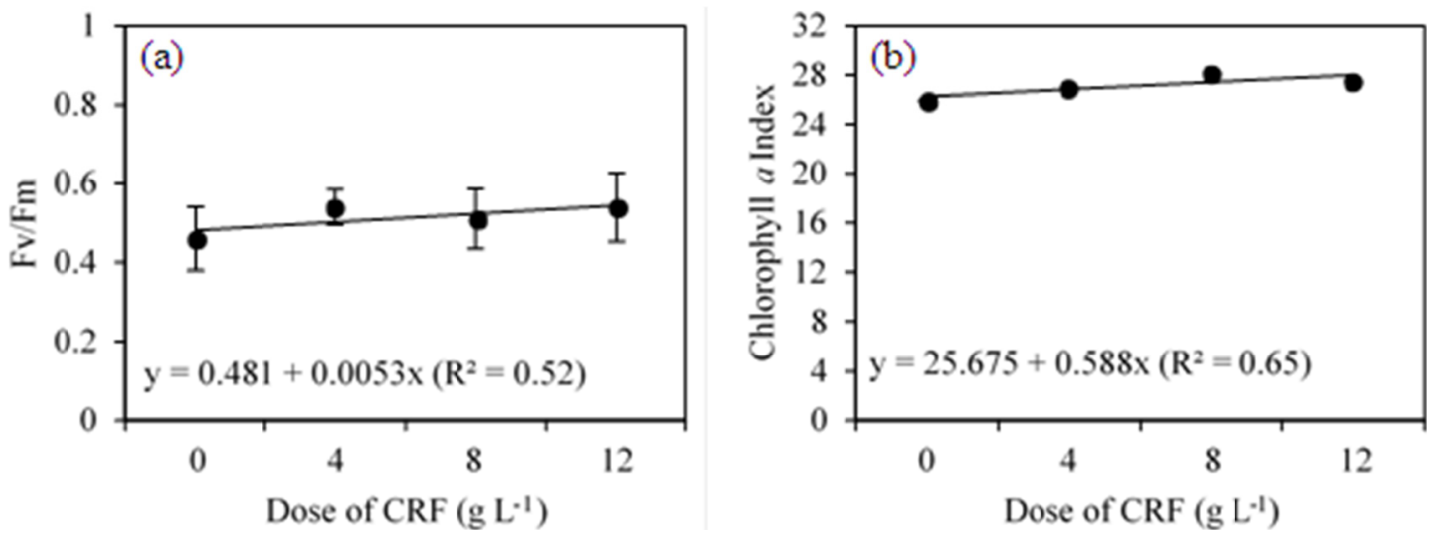

Figure 6. Maximum quantum yield $\left(\mathrm{F}_{\mathrm{v}} / \mathrm{F}_{\mathrm{m}}\right)(\mathrm{a})$ and the chlorophyll content $(\mathrm{b})$ of Handroanthus heptaphyllus seedlings at $540 \mathrm{~d}$ after planting, depending on the controlled release fertilizer (CRF) dose, in field

\section{Discussion}

\subsection{Seedlings Grown in Nursery}

CRF doses above the maximum estimated dose did not influence growth in $\mathrm{H}$ or $\mathrm{H}$ :SD of $H$. heptaphyllus seedlings. A similar result was observed by Gasparin et al. (2015) for the species Parapiptadenia rigida, where growth reduced at higher doses. According White (2012), such behavior is due to the toxicity or induced deficiency of some nutrients by the excess of others. Thus, we show that after meeting the nutritional demand of the plant, a higher fertilization will not result in a growth response, especially for $\mathrm{H}$ and $\mathrm{H}: \mathrm{SD}$. This phenomenon is characterized, according to Larcher (2000), as "luxury consumption" and can cause toxicity in plants.

On the other hand, the TDW and DQI variables presented the best results at the maximum dose used. TDW is a direct reflection of the net photosynthesis, an important factor for the initial growth of the plants in the field, since these plants initially depend on the photosynthates stored by the seedlings (Kozlowski et al., 1991). In this sense, Batista et al. (2014) considered that higher the value of this variable, the better the quality of the seedling.

When produced at a dose of $12 \mathrm{~g} \mathrm{~L}^{-1} \mathrm{CRF}, H$. heptaphyllus seedlings obtained a DQI of 0.18. Birchler et al. (2008) indicated that at values higher than 0.20 seedlings presented quality, a high rate of survival, and growth after planting. The DQI is an important indicator of seedling quality (Gomes \& Paiva, 2011), as it considers the robustness and balance of biomass distribution (Fonseca et al., 2002).

High values for SDW, LA, and RL attributes were observed in $H$. heptaphyllus seedlings grown in $500 \mathrm{~cm}^{3}$ polyethylene bags with the addition of $12 \mathrm{~g} \mathrm{~L}^{-1} \mathrm{CRF}$. This is primarily due to the higher volume of substrate, which allows for better development of the root system, in turn expanding the area of water and nutrient absorption and directly favoring the growth of the plant (Freitas et al., 2013).

The volume of the container also influenced $\mathrm{H}$ and TDW, and there was a restriction in the development of these variables in the 180 and $280 \mathrm{~cm}^{3}$ tubes in the nursery. In a study using seedlings of Hymenaea courbaril, Tabebuia chrysotricha, and Parapiptadenia rigida, Ferraz and Engel (2011) verified that the seedlings produced in $300 \mathrm{~cm}^{3}$ containers provided higher $\mathrm{H}$ and $\mathrm{SD}$, as well as greater development of aerial parts and root systems, compared to those grown in 50 and $110 \mathrm{~cm}^{3}$ containers. Additionally, Abreu et al. (2014) noted that seedlings tended to have a balanced growth between shoots and roots; however, when a limitation is imposed on the root system, shoot growth is also impaired.

In physiological terms, H. heptaphyllus seedlings presented higher values for the $\mathrm{F}_{\mathrm{v}} / \mathrm{F}_{\mathrm{m}}$ variable when produced at a dose of $12 \mathrm{~g} \mathrm{~L}^{-1}$ CRF. Several studies have demonstrated a positive correlation between $\mathrm{F}_{\mathrm{v}} / \mathrm{F}_{\mathrm{m}}$ and the concentration of nutrients in leaves (Loustau et al., 1999; Laing et al., 2000; Morales et al., 2000). Jacobs et al. (2005) also observed that seedlings of forest species demonstrated a significant increase in $F_{v} / F_{m}$ with the use of CRF. Seedlings produced under adequate nutritional conditions tended to show an increase in the operational 
efficiency of PSII (Maxwell \& Johnson, 2000), resulting in an increased net photosynthetic rate (Jacobs et al., 2005).

Based on our results, we recommend a dose of $12 \mathrm{~g} \mathrm{~L}^{-1} \mathrm{CRF}$ for the production of quality H. heptaphyllus seedlings, corroborating with the findings of Rorato et al. (2016) for Eugenia involucrata seedlings. This dose represents twice of that recommended by the CRF manufacturer, and is higher than indicated for other native species, such as Anadenanthera colubrina (Brondani et al., 2008), Parapiptadenia rigida (Gasparin et al., 2015) and Cabralea canjerana (Aimi et al., 2016).

We show that the different native forest species vary in their nutritional requirements. This underscores the importance of supplying the appropriate nutrients to a species in the nursery, allowing the production of quality seedlings, which improves its post-planting performance, ultimately reducing operational costs resulting from the replacement of dead seedlings.

\subsection{Planting Seedlings in the Field}

Although high, the dose efficiency of $12 \mathrm{~g} \mathrm{~L}^{-1} \mathrm{CRF}$ was confirmed in the field, unlike the container volume that did not influence seedling growth after field planting. Thus, it is evident that seedlings produced with the highest CRF dose recorded better morphophysiological characteristics, which was reflected in the quality and response of the seedlings after planting. On the other hand, as Freitas et al. (2005) suggested, restrictions in the nursery can reduce growth after planting, thus increasing replacement, maintenance, and control costs.

The positive establishment in the field of seedlings produced in the nursery with $12 \mathrm{~g} \mathrm{~L}^{-1} \mathrm{CRF}$ is associated with the highest observed root system. The root system might have favored better establishment, increasing soil surface area contact, resulting in a higher nutrient uptake for plant growth.

At the end of the field experiment, there was no significant difference between the container volumes. This result differs from that observed in the nursery, in which the $500 \mathrm{~cm}^{3}$ bag provided the highest growth. Close et al. (2009) evaluated seedlings of Eucalyptus globulus 4 y after planting and verified that container volume does not affect long-term growth. This reinforces the findings described by José et al. (2005), who reported that differences in growth, provided by the distinct volumes of the containers used during the production phase, tend to disappear as individuals become established in the field over time.

The positive response to the use of CRF in the production of $H$. heptaphyllus seedlings can be evidenced by the analysis of the maximum quantum yield $\left(\mathrm{F}_{\mathrm{v}} / \mathrm{F}_{\mathrm{m}}\right)$ and relative index of chlorophyll $a$. The results of the present study demonstrate $H$. heptaphyllus as a species responsive to fertilization, and are consistent with those observed in species of the Bignoniaceae family (Kitajima \& Hogan, 2003).

Seedlings produced with $12 \mathrm{~g} \mathrm{~L}^{-1} \mathrm{CRF}$ demonstrated the best performance both in the nursery and after planting in the field, while the container volume influenced only nursery performance. In coclusion, $180 \mathrm{~cm}^{3}$ tube is the most suitable size, due to the substrate economy provided. It is important to evaluate the results obtained in nurseries along with field planting and indicate silvicultural inputs and techniques that will actually influence the growth of seedlings.

\section{Conclusions}

Handroanthus heptaphyllus responds positively to base fertilization. We therefore recommend the use of 180 $\mathrm{cm}^{3}$ polypropylene tubes and $12 \mathrm{~g} \mathrm{~L}^{-1}$ of controlled release fertilizer in the production of these seedlings in the nursery. The post-planting performance of $H$. heptaphyllus is influenced by the way seedlings are produced, in that the best results were achieved by plants that received better nutritional conditions in the nursery.

\section{References}

Abreu, A. H. M., Leles, P. S. S., Melo, L. A., Ferreira, D. H. A. A., \& Monteiro, F. A. S. (2014). Produção de mudas e crescimento inicial em campo de Enterolobium contortisiliquum produzidas em diferentes recipientes. Floresta, 45(1), 141-150. https://doi.org/10.5380/rf.v45i1.28931

Aimi, S. C., Araujo, M. M., León, E. B., Oliveira, G. G., \& Silva, F. C. (2016). Volumen de contenedores y dosis de fertilizante de liberación controlada en el crecimiento de plantas de Cabralea canjerana producidas en vivero. Bosque (Valdivia), 37(2), 401-407. https://doi.org/10.4067/S0717-92002016000200018

Backes, P., \& Irgang, B. (2002). Árvores do sul: Guia de identificação e reconhecimento ecológico. Palloti, Porto Alegre. 
Batista, R. O., Martinez, M. A., Paiva, H. N. D., Batista, R. O., \& Cecon, P. R. (2014). O efeito da água residuária da suinocultura no desenvolvimento e qualidade de mudas de Eucalyptus urophylla. Ciência Florestal, 24, 127-135. https://doi.org/10.5902/1980509813330

Birchler, T., Royo, A., \& Pardos, M. (2008). La planta ideal: Revision del concepto, parametros definitorios e implementacion practica. Investigacion Agrária, Sistemas y Recursos Forestales, 13.

Brondani, G. E., Silva, A. J. C., Rego, S. S., Grisi, F. A., Nogueira, A. C., Wendling, I., \& Araujo, M. A. D. (2008). Fertilização de liberação controlada no crescimento inicial de angico-branco. Scientia Agraria, 9(2), 167-176. https://doi.org/10.5380/rsa.v9i2.10965

Campos Filho, E. M., \& Sartorelli, P. A. R. (2015). Guia de árvores com valor econômico. Agroicone, São Paulo.

Carvalho Filho, J. L., S., Blank, M. d. F. A., \& Rangel, M. S. A. (2003). Produção de mudas de jatobá (Hymenaea Courbaril L.) em diferentes ambientes, recipientes e composições de substratos. Revista Cerne, 1, 109-118.

Carvalho, P. E. R. (2003). Espécies arbóreas brasileiras. Colombo, PR.

Close, D. C., Paterson, S., Corkrey, R., \& Mcarthur, C. (2009). Influences of seedling size, container type and mammal browsing on the establishment of Eucalyptus globulus in plantation forestry. New Forests, $39,105$. https://doi.org/10.1007/s11056-009-9158-3

Coradin, L., Siminski, A., \& Reis, A. (2011). Espécies nativas da flora brasileira de valor econômico atual ou potencial: Plantas para o futuro região sul. MMA, Brasília.

Dickson, A., Leaf, A. L., \& Hosner, J. F. (1960). Quality appraisal of white spruce and white pine seedling stock in nurseries. The Forestry Chronicle, Mattawa, 36, 10-13. https://doi.org/10.5558/tfc36010-1

Dutra, A. F., Araujo, M. M., Turchetto, F., Rorato, D. G., Aimi, S. C., Gomes, D. R., \& Nishijima, T. (2016). Substrate and irrigation scheme on the growth of Parapiptadenia rigida (Angico-vermelho) seedlings. Ciência Rural, 46(6), 1007-1013. https://doi.org/10.1590/0103-8478cr20141732

Elli, E. F., Cantarelli, E. B., Caron, B. O., Monteiro, G. C., Pavan, M. A., Pedrassani, M., \& Eloy, E. (2013). Osmocote $^{\circledR}$ no desenvolvimento e comportamento fisiológico de mudas de pitangueira. Comunicata Scientiae, 4, 377-384.

Ferraz, A. D. V., \& Engel, V. L. (2011). Efeito do tamanho de tubetes na qualidade de mudas de jatobá (Hymenaea courbaril L. Var. Stilbocarpa (Hayne) Lee Et Lang.), Ipê-Amarelo (Tabebuia chrysotricha (Mart. Ex Dc.) Sandl.) e Guarucaia (Parapiptadenia rigida (Benth.) Brenan). Revista Árvore, 35, 413-423. https://doi.org/10.1590/S0100-67622011000300005

Ferreira, D. F. (2014). Sisvar: A guide for its bootstrap procedures in multiple comparisons. Ciência e Agrotecnologia, 38(2), 109-112. https://doi.org/10.1590/S1413-70542014000200001

Fonseca, É. D. P., Valéri, S. V., Miglioranza, É., Fonseca, N. A. N., \& Couto, L. (2002). Padrão de qualidade de mudas de Trema micrantha (L.) Blume, produzidas sob diferentes períodos de sombreamento. Revista Árvore, 26, 515-523. https://doi.org/10.1590/S0100-67622002000400015

Freitas, T. A. S. D., Fonseca, M. D. S., Souza, S. S. M. D., Lima, T. M., Mendonça, A. V. R., \& Santos, A. P. D. (2013). Crescimento e ciclo de produção de mudas de Eucalyptus em recipientes. Pesquisa Florestal Brasileira, 33(76). https://doi.org/10.4336/2013.pfb.33.76.575

Freitas, T. A. S., Barroso, D. G., Carneiro, J. G., Penchel, R. M., Lamônica, K. R., \& Ferreira, D. A. (2005). Desempenho radicular de mudas de eucalipto produzidas em diferentes recipientes e substratos. Revista Árvore, 29, 853-861. https://doi.org/10.1590/S0100-67622005000600003

Gasparin, E., Araujo, M. M., Saldanha, C. W., \& Tolfo, C. V. (2015). Controlled release fertilizer and container volumes in the production of Parapiptadenia rigida (Benth.) Brenan seedlings. Acta Scientiarum. Agronomy, 37(4), 473-481. https://doi.org/10.4025/actasciagron.v37i4.19528

Gasparin, E., Avila, A. L. D., Araujo, M. M., Cargnelutti Filho, A., Dorneles, D. U., \& Foltz, D. R. B. (2014). Influência do substrato e do volume de recipiente na qualidade das mudas de Cabralea canjerana (Vell.) Mart. em viveiro e no campo. Ciência Florestal, 24(3), 553-563. https://doi.org/10.5902/1980509815731

Gomes, J. M., \& Paiva, H. N. (2011). Viveiros Florestais: Propagação Sexuada. UFV, Viçosa. 
Gonçalves, J. L. d. M., Stape, J. L., Laclau, J.-P., Smethurst, P., \& Gava, J. L. (2004). Silvicultural effects on the productivity and wood quality of Eucalypt plantations. Forest Ecology and Management, 193, 45-61. https://doi.org/10.1016/j.foreco.2004.01.022

Gonçalves, J. L. M., Santarelli, E. D., Moraes Neto, S. P. D., \& Manara, M. P. (2005). Produção de mudas de espécies nativas: substrato, nutrição, sombreamento e fertilização. In J. L. M. Gonçalves, \& V. Benedetti, (Eds.), Nutrição e fertilização florestal (pp. 309-350). IPEF, Piracicaba.

Grochanke, B. S., Gehrke, I. T. S., Goettems-Fiorin, P. B., Bruxel, M. A., Basso, E. G. P., Heck, T. G., \& Ludwig, M. S. (2016). Compostos fenólicos da casca de Handroanthus heptaphyllus (Mart.) Mattos e efeitos do extrato aquoso no perfil lipídico, glicêmico e na lipoperoxidação em ratos diabéticos. Revista Brasileira de Plantas Medicinais, 18(1), 264-272. https://doi.org/10.1590/1983-084X/15_129

Heldwein, A. B., Buriol, G. A., \& Streck, N. A. (2009). O clima de Santa Maria. Ciência \& Ambiente, 38, 44-58.

Jacobs, D. F., Salifu, K. F., \& Seifert, J. R. (2005). Growth and nutritional response of hardwood seedlings to controlled-release fertilization at outplanting. Forest Ecology and Management, 214(3), 28-39. https://doi.org/10.1016/j.foreco.2005.03.053

José, A. C., Davide, A. C., \& Oliveira, S. L. (2005). Produção de mudas de aroeira (Schinus terebinthifolius Raddi) para recuperação de áreas degradadas pela mineração de bauxita. Cerne, 11(2), 187-196.

Kitajima, K., \& Hogan, K. P. (2003). Increases of chlorophyll a/b ratios during acclimation of tropical woody seedlings to nitrogen limitation and high light. Plant, Cell \& Environment, 26, 857-865. https://doi.org/ 10.1046/j.1365-3040.2003.01017.x

Klooster, W. S., Cregg, B. M., Fernandez, R. T., \& Nzokou, P. (2012). Growth and physiology of deciduous shade trees in response to controlled-release fertilizer. Scientia Horticulturae, 135(24), 71-79. https://doi.org/10.1016/j.scienta.2011.12.009

Kozlowski, T. T., Kramer, P. J., \& Pallardy, S. G. (1991). The physiological ecology of woody plants. Academic Press, New York. https://doi.org/10.1093/treephys/8.2.213

Laing, W., Greer, D., Sun, O., Beets, P., Lowe, A., \& Payn, T. I. M. (2000). Physiological Impacts of Mg Deficiency in Pinus Radiata: Growth and Photosynthesis. New Phytologist, 146, 47-57. https://doi.org/10.1 046/j.1469-8137.2000.00616.x

Larcher, W. (2000). Ecofisiologia Vegetal. RiMa, São Carlos.

Lorenzi, H. (2002). Árvores brasileiras: manual de identificação e cultivo de plantas arbóreas do Brasil. Nova Odesa: Instituto Plantarum, Brasil.

Loustau, D., Brahim, M. B., Gaudillère, J.-P., \& Dreyer, E. (1999). Photosynthetic responses to phosphorus nutrition in two-year-old maritime pine seedlings. Tree Physiology, 19, 707-715. https://doi.org/10.1093/ treephys/19.11.707

Maxwell, K., \& Johnson, G. N. (2000). Chlorophyll Fluorescence $a$ Practical Guide. Journal of Experimental Botany, 51, 659-668. https://doi.org/10.1093/jexbot/51.345.659

Mgeni, A. S. M., \& Price, C. (1993). Planning of forest plantation investments with the aid of linear programming: a case study of sao hill forest, Tanzania. Forest Ecology and Management, 62(4), 51-72. https://doi.org/10.1016/0378-1127(93)90041-K

Morales, F., Belkhodja, R., Abadía, A., \& Abadía, J. (2000). Energy Dissipation in the Leaves of Fe - Deficient Pear Trees Grown in the Field. Journal of Plant Nutrition, 23, 1709-1716. https://doi.org/10.1080/01 904160009382135

Omari, K., Maclean, D. A., Lavigne, M. B., Kershaw Jr, J. A., \& Adams, G. W. (2016). Effect of local stand structure on leaf area, growth, and growth efficiency following thinning of white spruce. Forest Ecology and Management, 368, 55-62. https://doi.org/10.1016/j.foreco.2016.03.005

Rorato, D. G., Araujo, M. M., Dutra, A. F., Turchetto, F., Berghetti, Á. L. P., \& Mieth, P. (2016). Effect of different container volumes and concentration of the controlled release fertilizer in the production of Eugenia involucrata Dc. Seedlings. African Journal of Agricultural Research, 11(46), 4762-4767. https://doi.org/10.5897/AJAR2016.11835

Shaviv, A. (2001). Advances in controlled-release fertilizers. Advances in Agronomy, 71, 1-49. https://doi.org/ 10.1016/S0065-2113(01)71011-5 
Tropicos. (2017). Missouri Botanical Garden.

Viana, J. S., Gonçalves, E. P., Andrade, L. A., Oliveira, L. S. B., \& Silva, E. O. (2008). Crescimento de mudas de Bauhinia forficata Link. em diferentes tamanhos de recipientes. Floresta, 38, 663-671. https://doi.org/ 10.5380/rf.v38i4.13161

White, P. J. (2012). Ion uptake mechanisms of individual cells and roots: Short-distance transport. In P. Marschner (Eds.), Marschner's Mineral Nutrition of Higher Plants (pp. 7-47). Academic, London. https://doi. org/10.1016/B978-0-12-384905-2.00002-9

Zór, K., Mark, C., Heiskanen, A., Madsen, C. K., Dufva, M., Emnéus, J., Brinch-Pedersen, H., \& Finnie, C. (2017). Immobilisation of barley aleurone layers enables parallelisation of assays and analysis of transient gene expression in single cells. Plant Physiology and Biochemistry, 118, 71-76. https://doi.org/ 10.1016/j.plaphy.2017.06.008

\section{Copyrights}

Copyright for this article is retained by the author(s), with first publication rights granted to the journal.

This is an open-access article distributed under the terms and conditions of the Creative Commons Attribution license (http://creativecommons.org/licenses/by/4.0/). 